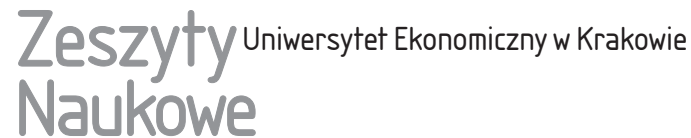

\section{Extending Means-end Chain Theory by Integrating a Self-concept Approach and Behavioural Perspective Model}

\begin{abstract}
This methodological and concept paper attempts to combine the recently emerged, yet well-established, value-based cognitive model - Means-end Chain (MEC) - with the self-concept approach and the Behavioural Perspective Model (BPM). The paper has three aims: first, to elaborate the MEC theory, the post-modern approach of self-concept and the hermeneutical model based on radical behaviourism, BPM. Second, to discuss the similarities and differences with MEC and, third, to formulate a novel extended MEC metatheory.

The theoretical framework is based on a critical overview of scientific books and articles. It includes an examination of the elements to enhance the MEC model with symbolism, dynamics and multi-dimensionality on the micro-level through integration of the self-concept approach. It also investigates the environmental, reinforcing / aversive and experiential aspects of the BPM on the macro level.

The results of the exploration pave the way to the new research extended MEC EMEC - which opens up new opportunities to redesign and re-systemise the interpretation and understanding of consumer behaviour.
\end{abstract}

Keywords: consumer behaviour, Means-end Chain Theory, self-concept, Behavioural Perspective Model.

JEL Classification: M30, M31, M37.

Elena Borgardt, Doctoral Studies, Cracow University of Economics, e-mail: borgardt.elena@gmail.com, ORCID: https://orcid.org/0000-0002-1902-8754. 


\section{An Overview of Means-end Chain Theory}

\subsection{General Remarks}

The "means-end chain approach" is an idiosyncratic umbrella term that comprises a myriad of qualitative and quantitative methods to elicit deep, underlying consumer values at different levels of abstraction (Understanding... 2001). While considerable theoretical and empirical literature has been produced on this approach, the Means-end Chain (MEC) in its current form seems to have reached the limits of its academic development and practical applications. This paper addresses this problem, by presenting a novel conceptual and methodological framework - EMEC, outlining a promising scenario for future research. EMEC enlarges the epistemological status of MEC, from the purely cognitive view prevailing in science today to a more motivational research approach that deals with situational and impetus constructed meanings. Thus, the self-concept approach (micro-level) and the BPM (macro-level) combined with the MEC form synergies and open up new avenues of thought to enhance the model with symbolism, dynamism and multi-dimensionality (Borgardt 2018).

\subsection{Conventional Means-end Chain Theory}

MEC theory is a value-based, cognitive model used to better understand consumer behaviour and decision-making. It connects the tangible attributes of a product (the means) to highly abstract and intangible personal and emotional values (the ends) (Understanding... 2001). Inspired by G. Kelly's work (Grunert \& Bech-Larsen 2005, Ferran \& Grunert 2007), T. Reynolds and J. Gutman introduced the means-end approach to the field of marketing and consumer research. Researchers postulate the existence of hierarchically organised relationships, connecting product attributes (A), consequences (C) and individual values (V) (Chin-Feng, Hsien-Tang \& Chen-Su 2006). The A-C-V ladder chain provides an understanding of the salient factors and their personal importance to consumers as they make decisions.

MEC theory is a sequential process that can be assessed in three steps: identification of salient product attributes, a laddering procedure and analysis of the data and plotting of the Hierarchical Value Maps (HVM). Salient product attributes that are important for consumers can be identified using techniques based on sorting procedures, elicitation, ranking or scaling tasks. These techniques originate from cultural domain taxonomies and aim to distinguish objects according to their perceived similarities or differences (Understanding... 2001, Bernard 2011). 
The laddering interview identifies why particular attributes are important to the consumer in a projected situation, once the most important, salient attributes have been determined. Laddering is classified into soft and hard techniques. Soft laddering is applied in research with an exploratory character (Doing Social... 2008) and has a qualitative appeal. Consumers are prompted to answer a series of probing questions which help researchers understand why given attributes are relevant to the consumers in terms of their benefits and drawbacks. Hard laddering is a more structured, more mechanistic interview model that asks consumers to generate associations (Understanding... 2001).

Analysis of the data collected encompasses a large number of conventional and modern methods which facilitate the interpretation of results originating from laddering (e.g. multivariate methods, regression, Structural Equation Model).

HVM, also called Consumer Decision Maps (CDM), are an easy-to-interpret, tree diagramme presentation of laddering interviews (Understanding... 2001). It is constructed based on a summary implication matrix or an SIM of aggregated individual ladders (Understanding... 2001, Kaciak 2011). Mecanalyst Plus and Laddermap are the most frequently used software to plot HVMs.

Thanks to the wide range of benefits MEC theory offers, it has gained in popularity in numerous fields: marketing, with a focus on MECCAS (Means-end Conceptualisation of the Components of Advertising Strategy) (Bech-Larsen 2000, Søndergaard 2005), brand equity analysis (Wansink 2003), consumer involvement (Lind 2007), politics (Bagozzi \& Dabholkar 2000, Phillips, Reynolds \& Reynolds 2010), e-banking (Kuisma, Laukkanen \& Hiltunen 2007) and social networking (Aschmoneit \& Heitmann 2002).

\subsection{The Self-concept Approach Integrated into MEC}

Basically, goal-oriented MEC theory is a comprehensive model and a useful framework for understanding consumer behaviour and decision-making. However, with respect to amplitude there are a few notable gaps on the micro- and macro-levels. A potential micro-level improvement would be to integrate a self-concept approach, where values that are essential to the individual reflect the awareness and perceptions one has of oneself and, consequently, provide an in-depth understanding of the consumer's personality to find new ways to trigger consumer behaviour. On the macro level, the MEC could obtain dynamics in terms of environmental, reinforcing/aversive and experiential aspects (Borgardt 2017). Hence, bridging the micro-level (self-concept approach), the MEC and the macro-level (BPM) could bring about a more systematic view in value-based and goal-oriented MEC theory. 
Principally, self-concept is a complex notion that has been treated from different theoretical points of view. Psychoanalytic or Freudian theory considers the "Self" as a system of competing, conflicted forces. Behavioural theory assigns the "Self" as a bundle of conditioned responses while the cognitive perspective characterises the "Self" as a system, processing information about the self (Solomon et al. 2006, Proceedings... 2015).

Apart from that, debate continues as to whether the "Self" is a unidimensional concept, where it is treated as ideal, actual self or extended self; or whether it is a multidimensional construct involving a variety of notions, thus being individualistic, identity-forming, symbolic and experiential in nature (Blaiech, Gharbi \& Hamouda 2013).

Following E. C. Hirschman's and M. B. Holbrook's view (Hirschman \& Holbrook 1982), representatives of post-modern marketing, personality and values are tightly correlated and in that sense:

- value is an interaction between a subject (individuum) and an object (product) and values are changeable across individuals;

- the purchase of goods by a person is not considered from a neoclassical, utilitarian perspective, but from one of experience (Sánchez-Fernández \& Iniesta-Bonillo 2007);

- the individual prefers products with images that are congruent with his or her self-concept (self-congruent products);

- the individual is directed to enhance his or her self-concept/identity through products, communicating symbolic meaning;

- personal values are comparative and situational (Consumer Value... 1999).

Going deeper into M. B. Holbrook's comprehensive typology of the consumer value approach (Holbrook 1996, Consumer Value... 1999), three key dimensions of consumer/personal values will be further interrelated with MEC theory:

- extrinsic value (consumption is appreciated for its instrumentality as a means to ends relationship) versus intrinsic value (consumption experience as an end in itself);

- self-oriented (values are prised for the individual's own sake) versus other-oriented value (consumption beyond the self to someone else);

- active values (physical or mental manipulation of a product) versus reactive (the experiential impact the product has on the consumer) (Consumer Value... 1999, Sánchez-Fernández \& Iniesta-Bonillo 2007).

Other post-modern adherents emphasise the "multiphrenic self," a concept that implies the existence of different personalities/identities in the same individual at a given time, which could lead to contradictory and paradoxical behaviours. This means that the post-modern individual looks for a multiplicity of images and personalities to better adapt him or herself (Hamouda 2012). 
The holistic, post-modern marketing view of the self-concept may afford an interesting opportunity for integration into MEC theory. Obviously, the basic assumptions of both input models - product attributes and personal and emotional values - coincide as the means and the ends, respectively (Understanding... 2001). Apart from that, the key dimensions of consumer/personal values elaborated by E. C. Hirschman and M. B. Holbrook are interwoven with MEC theory, though one aspect of MEC analysis stands apart: it provides a way to link consumption to values indirectly, without clear consideration of an experiential end-in-itself in the process (Consumer Value... 1999).

MEC sufficiently depicts the link between the consequences of consumption and consumption values. However, the connection of higher order consumption values is equivocally interlinked with personal values (Consumer Value... 1999).

As regards the "Self" in a situational context, the MEC's "specific" and "broad" approaches with projection of situation in consumers' minds (Grunert, Grunert \& Sørensen 1995) could be considered static and simplistic, with a fixed number of values at the end of the chain. The "multiphrenic self" in a post-modern view, on the other hand, is dynamic and could be driven by several, differentiating goals to satisfy the personalities/identities in place (Hamouda 2012).

As M. Rokeach (1973) has written, it is very rare that any situation encountered in life will activate a single value. Most situations will involve a conflict among several values, which the individual will resolve according to his or her value priorities or value system (Kamakura \& Novak 1992). Value-based and goal-oriented MEC theory, in combination with the postmodern self-concept (microlevel) marketing approach, with its multi-faceted vision of symbolism, unique meanings, feelings, experience, and pleasure, are necessary to redesign and re-systemise the interpretation and understanding of consumer behaviour and the decision-making process within the MEC framework.

\subsection{The Behavioural Perspective Model Incorporated into MEC}

Cognitive theories with an emphasis on mental structures and thinking processes are very motivating and manoeuvre-free in explaining consumer behaviour. Yet behavioural approaches, which emphasise the direct link between the environment and the individual's behaviour, increase the predictability and control of consumer behaviour. Elements from behavioural models could thus be promising enhancement instruments in the study of consumer behaviour and marketing (Foxall, Oliveira-Castro, James, Yani-de-Soriano \& Sigurdsson 2006).

The BPM is a hermeneutical model based on radical behaviourism, Skinner's operant conditioning and a single-subject research strategy (Foxall 2004).

G. R. Foxall describes BPM as "the rate at which consumer behaviours take place as a function of the relative openness of the setting in which they occur 
and the informational and utilitarian reinforcement available or promised by the setting" (Foxall et al. 2007).

At the heart of the model are situational variables that determine behaviour, with a specific focus on antecedent events and the individual's forthcoming responses. Hence BPM is a three-term contingency model, consisting of discriminative stimulus, response and reinforcing or punishing / aversive consequences: $S^{D} \rightarrow R \rightarrow S^{R / P}$ (Foxall, Oliveira-Castro, James \& Schrezenmaier 2006).

In line with the BPM model, consumer behaviour is located at the intersection of a consumer-behaviour setting and an individual's learning history of consumption and is a function of utilitarian and informational reinforcements (Foxall, Oliveira-Castro, James, Yani-de-Soriano \& Sigurdsson 2006). According to BPM, consumer behaviour, and with it the consumer response rate (dependent variable), is determined by the consumer-behaviour setting (antecedent variable), which could vary in scope from relatively closed to relatively open.

The consumer-behaviour setting can be divided into physical, social, temporal (time-based) and regulatory (rule-based) antecedent discriminative stimuli (Foxall 1998). Consumer behaviour in relatively closed situations, with a limited number of alternatives / reinforcements, such as casino gambling, tends to comply with established directives to avoid aversive consequences, thus making the response more predictable and bringing it under greater control. Relatively open settings lessen the likelihood of foreseeing the consumers' behaviour, because here consumers have more choice and self-motivation and are guided more by positive reinforcement. Supermarkets are a typical open setting context.

Utilitarian and informational reinforcement bifurcate within the category of consumer behaviour, and can be both reinforcing and aversive. Utilitarian reinforcement ${ }^{1}$ refers to a product's technical functions and reflect value-in-use, as well as feelings associated with owning and using the product (sensory stimulation, pleasure). Utilitarian forms of reinforcement can be both primary and secondary in nature, and are also considered contingency-derived (Foxall 1998).

Informational reinforcement ${ }^{2}$ consists of symbolic, socially determined functions, akin to exchange value, which generate incentives and affect other peoples' behaviour (e.g. feedback on the individual's achievement, social acceptance or social status). Informational reinforcement, secondary in nature, is also called rule-derived reinforcement (Foxall 1998).

The synthesis of utilitarian and informational reinforcement and the pairing of primary and secondary stimuli configure the consumer's unique learning history

1 The utilitarian reinforcement of buying a car is the benefit of owning and using it, in a purely utility and hedonistic sense: door-to-door transportation, minimum weather exposure, flexibility, etc.

2 The informational reinforcement of owning a car could be associated with social status, prestige and the admiration of others (e.g. Bentley or Mercedes). 
(Foxall 2009). Aversive consequences generally lead to the cessation of a behaviour (e.g. purchase costs, car-related environmental pollution).

The individual's learning history describes the experience he or she has obtained in comparable situations in the past. The experience is either reinforced or weakened, influencing the likelihood of the behaviour reoccurring in the future.

Taking into account the combination of consumer-behaviour settings (relatively open versus relatively closed) and operant classes (pairing high/low utilitarian with high/low informational forms of reinforcement), G. R. Foxall elaborated eight contingency categories, which help to understand the complex nature of behaviour.

A very interesting phenomenon is that operant classes - accomplishment, hedonism, accumulation and maintenance - are also considered equifinality classes. This means that topographically different responses belong together due to their equal functionality and therefore produce identical consequences (Foxall 2009)3.

\section{Consumer Bahaviour Setting}

\begin{tabular}{|c|c|c|}
\hline \multirow[b]{2}{*}{$\begin{array}{l}\text { Accomplishment } \\
\text { High Utilitarian/ } \\
\text { High Informational } \\
\text { Reinforcement }\end{array}$} & \multicolumn{2}{|c|}{$\longleftrightarrow$} \\
\hline & $\begin{array}{l}\text { Fulfillment } \\
\text { Excitement, fulfillment, pleasure } \\
\text { and social approval: casino gam- } \\
\text { bling, personal development training }\end{array}$ & \begin{tabular}{|l} 
Status Consumption \\
Extended consumer behaviour/ \\
Extended problem solving: search \\
and evaluation for status symbols
\end{tabular} \\
\hline $\begin{array}{l}\text { Hedonism } \\
\text { High Utilitarian/ } \\
\text { Low Informational } \\
\text { Reinforcement }\end{array}$ & $\begin{array}{l}\text { Inescapable Entertainment / Relief } \\
\text { from Discomfort } \\
\text { Museum visit, inflight movie, meal } \\
\text { consumption, taking medication }\end{array}$ & $\begin{array}{l}\text { Popular Entertainment } \\
\text { Variety, pace and change: TV shows, } \\
\text { stories, listening to popular music }\end{array}$ \\
\hline $\begin{array}{l}\text { Accumulation } \\
\text { Low Utilitarian/ } \\
\text { High Informational } \\
\text { Reinforcement }\end{array}$ & $\begin{array}{l}\text { Token-based Consumption } \\
\text { Collecting through purchase-based } \\
\text { token economies: gathering trading } \\
\text { stamps, hotel points, "air miles" }\end{array}$ & $\begin{array}{l}\text { Saving and Collecting } \\
\text { Systematic collection or accumula- } \\
\text { tion of tokens: coupons, promotional } \\
\text { deals, installment buying }\end{array}$ \\
\hline $\begin{array}{l}\text { Maintenance } \\
\text { Low Utilitarian/ } \\
\text { Low Informational } \\
\text { Reinforcement }\end{array}$ & $\begin{array}{l}\text { Mandatory Consumption } \\
\text { Compulsory purchase and con- } \\
\text { sumption of state-enforced escape } \\
\text { commodities: TV licensing, health } \\
\text { insurance, pension-fund membership }\end{array}$ & $\begin{array}{l}\text { Routine Purchasing } \\
\text { Habitual purchasing of socialised } \\
\text { economic necessities: buying con- } \\
\text { sumer goods, having dental check-up }\end{array}$ \\
\hline
\end{tabular}

Fig. 1. The BPM Contingency Matrix

Source: the author, based on Foxall, Oliveira-Castro, James, Yani-de-Soriano and Sigurdsson (2006) and Foxall (2009).

${ }^{3}$ Ordering a perfume online and buying it at a specialised store fall under the same equifinal class because they have the same outcome. Yet, when two consumers enter a store at the same time and the same manner, their responses will belong to different operant classes, as the one is reinforced by product purchase per se, while the other looks for information about the product's quality and price. 
The left column of Figure 1 illustrates four operant classes of consumer behaviour, divided by pattern of reinforcement (i.e. high / low utilitarian and high/low informational). The operant classes, in their turn, can be operationalised alongside the scope of the setting (i.e. relatively open behaviour settings versus relatively closed behaviour settings) to build eight contingency categories to classify the behaviours. The immediate intersection of the MEC and the BPM act as a form of reinforcement, dealing with both utilitarian and informational values, which could serve as a starting point for the models' fusion. The situational context, learning history and consumer behavioural dynamism mentioned in the BPM could all be considered macro-level enhancement elements of MEC theory. MEC theory is based on the cognitive approach, and deals strictly with input and latent variables, while the BPM implicitly comprises both unobservable and observable variables, which could positively contribute to exposure of MEC theory.

Compared to MEC theory, BPM illustrates consumer behaviour as a comprehensive, dynamic mechanism, depending on the situational context. The point at which the consumer's cognitive structures are activated by situational factors in the MEC, however, still requires further investigation. Apart from that, information produced during the laddering interviews, in its standard form, did not enable reflection on the situational specificity the respondents had in mind (Understanding... 2001). Therefore, the merger of both theories could lead to new findings with regard to consumer behaviour.

The consumer, driven by his or her learning history, including episodic information (previous key experiences with products that are linked to a specific time, space) (Understanding... 2001), could be conflicted by a few outcome scenarios: either approaching valued desired end-states or avoiding undesired end-states. The point is that the MEC perfectly elucidates the positive values on the Hierarchical Value Maps (HVM), whereas the HVM based on negative laddering could completely fail to represent the values. In that respect, discoveries about reverse values could be of interest to researchers or marketers for the analysis and product strategy they enable (Zanoli \& Naspetti 2002).

One final question concerns whether equifinality will still retain its "finality" status while being integrated into the MEC; or if it will gain the character of a starting point in the redefined, dynamic MEC chain.

In summary, the combination of the value-based MEC theory and the stimulus-response BPM model could increase the overall understanding of consumer behaviour by providing a new perspective on the importance of purchasing and consumption. 


\section{New Extended Means-end Chain Theory (EMEC) Metatheory}

While the cognitive approaches that have prevailed in recent decades are strongly predictive of consumer behaviour, there is still potential to endow them with new, unconventional approaches.

Again, MEC is a value-based theory with a well-grounded and in-depth illustration of behaviour as a cognitive process, involving various levels of associations (Understanding... 2001). Merged in the memory, these levels provide the consumer with the personal impetus to move to achieve his or her goal.

\begin{tabular}{|c|c|c|c|c|c|c|}
\hline \multirow{5}{*}{$\begin{array}{l}\text { Closed } \\
\text { Environment/ } \\
\text { Setting }\end{array}$} & \multicolumn{3}{|c|}{$\begin{array}{l}\text { INFORMATIONAL } \\
\text { REINFORCEMENTS }\end{array}$} & \multicolumn{3}{|c|}{$\begin{array}{l}\text { UTILITARIAN } \\
\text { REINFORCEMENTS }\end{array}$} \\
\hline & \multicolumn{3}{|c|}{$\begin{array}{l}\text { 1st Dimension of MEC } \\
\text { Expression of symbolic, socially- } \\
\text {-determined and prestige functions } \\
\text { within relatively closed settings }\end{array}$} & \multicolumn{3}{|c|}{$\begin{array}{l}\text { 2nd Dimension of MEC } \\
\text { Manifestation of value-in-use functions } \\
\text { and feelings from owing the product } \\
\text { in relatively closed settings }\end{array}$} \\
\hline & \multicolumn{3}{|c|}{ Consumer Typologies } & \multicolumn{3}{|c|}{ Consumer Typologies } \\
\hline & $\begin{array}{c}\text { Extrinsic } \\
\text { Values }\end{array}$ & $\begin{array}{c}\text { Self- } \\
\text {-oriented } \\
\text { Values }\end{array}$ & $\begin{array}{l}\text { Active } \\
\text { Values }\end{array}$ & $\begin{array}{l}\text { Extrinsic } \\
\text { Values }\end{array}$ & $\begin{array}{c}\text { Self- } \\
\text {-oriented } \\
\text { Values }\end{array}$ & $\begin{array}{l}\text { Active } \\
\text { Values }\end{array}$ \\
\hline & $\begin{array}{l}\text { Intrinsic } \\
\text { Values }\end{array}$ & $\begin{array}{l}\text { Other- } \\
\text {-oriented } \\
\text { Values }\end{array}$ & $\begin{array}{c}\text { Reactive } \\
\text { Values }\end{array}$ & $\begin{array}{l}\text { Intrinsic } \\
\text { Values }\end{array}$ & $\begin{array}{l}\text { Other- } \\
\text {-oriented } \\
\text { Values }\end{array}$ & $\begin{array}{l}\text { Reactive } \\
\text { Values }\end{array}$ \\
\hline \multirow{4}{*}{$\begin{array}{l}\text { Open } \\
\text { Environment/ } \\
\text { Setting }\end{array}$} & \multicolumn{3}{|c|}{$\begin{array}{l}\text { 3rd Dimension of MEC } \\
\text { Demonstration of symbolic, socially- } \\
\text {-determined and prestige functions } \\
\text { within relatively open setings }\end{array}$} & \multicolumn{3}{|c|}{$\begin{array}{l}\text { 4th Dimension of MEC } \\
\text { Portrayal of value-in-use functions and } \\
\text { mental states from owing the product } \\
\text { in relatively open settings }\end{array}$} \\
\hline & \multicolumn{3}{|c|}{ Consumer Typologies } & \multicolumn{3}{|c|}{ Consumer Typologies } \\
\hline & $\begin{array}{l}\text { Extrinsic } \\
\text { Values }\end{array}$ & $\begin{array}{c}\text { Self- } \\
\text {-oriented } \\
\text { Values }\end{array}$ & $\begin{array}{l}\text { Active } \\
\text { Values }\end{array}$ & $\begin{array}{l}\text { Extrinsic } \\
\text { Values }\end{array}$ & $\begin{array}{c}\text { Self- } \\
\text {-oriented } \\
\text { Values }\end{array}$ & $\begin{array}{l}\text { Active } \\
\text { Values }\end{array}$ \\
\hline & $\begin{array}{c}\text { Intrinsic } \\
\text { Values }\end{array}$ & $\begin{array}{l}\text { Other- } \\
\text {-oriented } \\
\text { Values }\end{array}$ & $\begin{array}{l}\text { Reactive } \\
\text { Values }\end{array}$ & $\begin{array}{l}\text { Intrinsic } \\
\text { Values }\end{array}$ & $\begin{array}{l}\text { Other- } \\
\text {-oriented } \\
\text { Values }\end{array}$ & $\begin{array}{l}\text { Reactive } \\
\text { Values }\end{array}$ \\
\hline
\end{tabular}

Fig. 2. Extended Means-end Chain Constellation

Source: the author.

Since MEC explains behavioural intention once the relevant excerpts from cognitive structure and motivation are known (Understanding... 2001), it could be considered strictly an output tool. Consequently, symbolism, experience and feel- 
ings, originating from the self-concept, as well as the manipulation of environments in which the response and reward occur, are missing building blocks that could explain how, in a given situation and under given motivational constraints, certain parts of cognitive structure become relevant, thus bringing dynamics into MEC.

Figure 2 presents an overview of a new EMEC model, where the goal-oriented MEC is combined with the BPM model, generating four dimensions. Informational and utilitarian reinforcements are opposed to relatively closed versus relatively open settings/environments.

Searching for self-congruent, identity-forming products, the individual is directed by symbolic and experiential values concealed in the product during the decision-making process. MEC could thus also be filled in with the self-concept variables to bring a holistic, experiential aspect into the model.

Hence, four MEC dimensions, as a cross-section of the MEC and the BPM, are extended to six sub-categories each (extrinsic versus intrinsic values; self-oriented versus other-oriented; active values versus reactive values), producing 24 sub-dimensions to define the consumer typologies of the overall EMEC.

While all consumer typologies could come into play simultaneously, they are not of equal primacy. Hence, Figure 2 distinguishes between supreme/primary (darker grey) and subordinate/secondary (lighter grey) consumer typologies that become relevant in the presence of informational/utilitarian forms of reinforcement and in closed/open settings.

Consequently, the 1st dimension of MEC (informational reinforcements paired with the closed setting) defines extrinsic, self-oriented and reactive values as being of the greatest primacy. Intrinsic, other-oriented and active values are subordinate values. This means that:

- gathering tokens / points to obtain a special gift or prize, being admired or praised by a closed society, drinking tea in an exclusive cafeteria, personal development training, etc. could be considered the means to accomplishing specific goals viewed as desirable (extrinsic nature);

- the selfish or prudent appraisal of some aspect of consumption, for one's own sake, infers orientation of the self (self-orientation);

- apprehending, appreciating and admiring the result of consumption on consumer points speaks to the reactive nature of values being activated (reactive values).

Visiting a museum, taking medication, watching in-flight movies, reading sensational literature, etc. are examples of the 2 nd dimension (utilitarian reinforcement contrasted with the closed setting); where intrinsic, self-oriented and reactive values predominate along with secondary extrinsic, other-oriented and active values:

- the intrinsic nature of these activities is comprised in its self-justification, consumption experience as an end in itself (intrinsic values); 


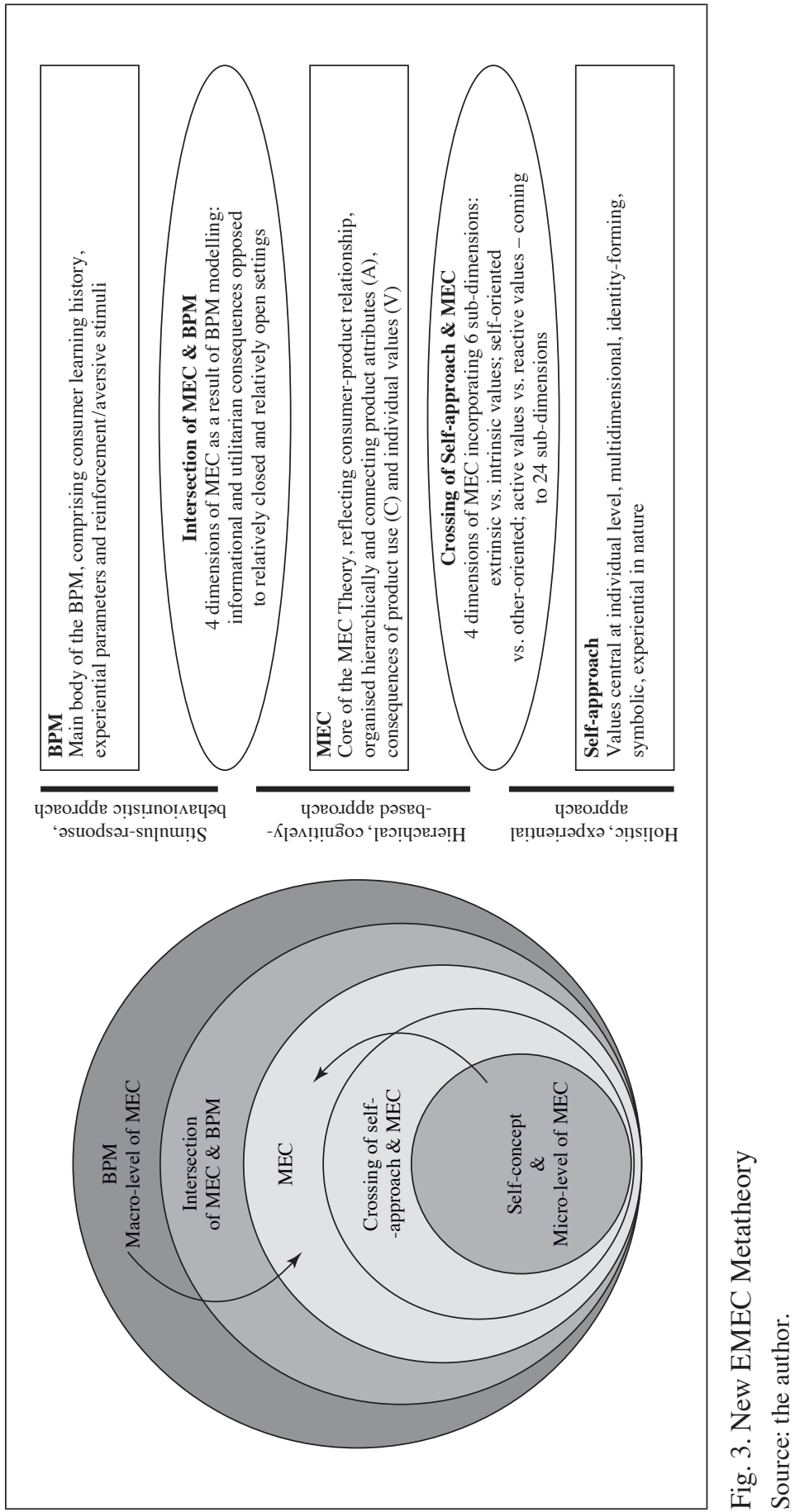


- self-orientation becomes apparent through the effect an event has on the person or contribution to my one's own experience (self-oriented values);

- a product's effect on the consumer depicts its reactive character (reactive values).

The 3rd dimension (informational reinforcement paired with the open setting) outlines intrinsic, self-oriented and reactive values as primary values, while extrinsic, other-oriented and active values play a secondary role. Examples of this dimension include going on holiday, investment in real estate, gesture / feedback for publicity and payment for prior consumption.

Examples of the 4th dimension (utilitarian reinforcement contrasted with the open setting) include owning a luxury car, looking for and evaluating status symbols, and feelings associated with winning/consuming a prize. Fourth dimension primary values include intrinsic, other-oriented and active values while secondary values include extrinsic, self-oriented and reactive ones.

To sum up, the 1st and 4th dimensions are the inversion of one another while the 2 nd and 3 rd dimensions emphasise the same sub-dimensions.

Figure 3 summarises the new multifaceted metatheory, which has MEC theory at its core; the self-concept approach, from a micro-level perspective, provides an in-depth understanding of the consumer's personality. On a macro-level, with the help of the BPM, the MEC obtains dynamics in terms of environmental, reinforcing/aversive and experiential aspects. The original models, used to form the new EMEC theory, can be found in the rectangles on the right side of the picture. The ovals mark the areas where the approaches intersect, making the new elements of the EMEC more obvious.

Based on the new representation of the model shown above, MEC theory obtains a full-scale, dynamic character. Issues that still require investigation are the causality between the elements, which of them is to be considered exogenous and which endogenous and whether there is a direct connection between them or whether mediator and/or moderator variables should be taken into consideration.

In a nutshell, only after all of these aspects have been examined can a significant contribution be made to consumer research, the prediction of behaviour and the development of successful product positioning and advertising.

\section{Conclusions}

This paper has presented an analysis of MEC theory, the post-modern approach of self-concept and the hermeneutical model based on radical behaviourism, BPM. The points of contact and differences with the conventional MEC theory has been revealed and as a consequence formulated a new unconventional EMEC metatheory. 
Although MEC has proven an effective tool for predicting consumer behaviour, a few gaps have been discovered on the micro- and macro-levels which the theory does not cover. As a result, a novel, post-modern approach to chain theory was proposed: EMEC, eliciting four MEC dimensions that blend the MEC and BPM models. Those four are further extended to six sub-categories of the self-concept each, producing a total of 24 new sub-dimensions, defining the new consumer typologies of the EMEC.

Owing to this novel EMEC metatheory, the paper opens new directions for theoretical and practical research involving the use of MEC in predicting consumer behaviour, developing successful products and advertising.

\section{Acknowledgement}

The author thanks Professor Adam Sagan for his guidance, essential comments and wise counsel on earlier drafts of this paper.

\section{Bibliography}

Aschmoneit P., Heitmann M. (2002), Customer Centred Community Application Design: Introduction of the Means-end Chain Framework for Product Design of Community Applications, "International Journal on Media Management", vol. 4, no 1, https://doi. org/10.1080/14241270209389976.

Bagozzi R. P., Dabholkar P. A. (2000), Discursive Psychology: An Alternative Conceptual Foundation to Means-end Chain Theory, "Psychology and Marketing", vol. 17, no 7, https://doi.org/10.1002/(sici)1520-6793(200007)17:7<535::aid-marl>3.0.co;2-h.

Bech-Larsen T. (2000), Model-based Development and Testing of Advertising Messages: A Comparative Study of Two Campaign Proposals Based on the Meccas Model and a Conventional Approach, "International Journal of Advertising. The Review of Marketing Communications", vol. 20, no 4, https://doi.org/10.1080/02650487.2001.11104908.

Bernard H. R. (2011), Research Methods in Anthropology: Qualitative and Quantitative Approaches, 5th ed., AltaMira Press, Lanham, MD.

Blaiech R., Gharbi A., Hamouda M. (2013), Postmodern Marketing: Towards a Convergence between the Individualistic Approach and the Tribal Approach, "Interdisciplinary Journal of Contemporary Research in Business", vol. 4, no 9.

Borgardt E. (2017), Motivation and Consumer Behavior, "Konsumpcja i Rozwój", no 4(21). Borgardt E. (2018), Conventional and Extended Versions of Means-end Chain Theory, "Zeszyty Naukowe Uniwersytetu Ekonomicznego w Krakowie", no 3(975), https://doi. org/10.15678/ZNUEK.2018.0975.0312.

Chin-Feng L., Hsien-Tang T., Chen-Su F. (2006), A Logic Deduction of Expanded Means-end Chains, "Journal of Information Science", vol. 32, no 1, https://doi. org/10.1177/0165551506059218.

Doing Social Psychology Research (2008), G. M. Breakwell (ed.), The British Psychological Society-Blackwell Publishing, Oxford. 
Ferran F., Grunert K. G. (2007), French Fair Trade Coffee Buyers' Purchasing Motives: An Exploratory Study Using Means-end Chains Analysis, "Food Quality and Preference", vol. 18, no 2, http://doi.org/10.1016/j.foodqual.2005.11.001.

Foxall G. R. (1998), Radical Behaviorist Interpretation: Generating and Evaluating an Account of Consumer Behavior, "The Behavior Analyst", vol. 21, no 2, https://doi. org/10.1007/bf03391971.

Foxall G. R. (2004), Consumer Psychology in Behavioral Perspective, Beard Books, Washington, DC.

Foxall G. R., Oliveira-Castro J. M., James V. K., Yani-de-Soriano M., Sigurdsson V. (2006), Consumer Behavior Analysis and Social Marketing: The Case of Environmental Conservation, "Behavior and Social Issues", vol. 15, no 1, https://doi.org/10.5210/ bsi.v15i1.338.

Foxall G. R., Oliveira-Castro J. M., James V. K., Schrezenmaier T. C. (2006), Consumer Behavior Analysis: The Case of Brand Choice, "Revista Psicologia: Organizeções e Trabalho", vol. 6, no 1.

Foxall G. R., Oliveira-Castro J. M., James V. K., Schrezenmaier T. C. (2007), The Behavioral Economics of Brand Choice, Palgrave Macmillan, London, https:// doi.org/10.1057/9780230596733.

Foxall G. R. (2009), Interpreting Consumer Choice: The Behavioral Perspective Model, Routledge Interpretive Marketing Research, Routledge, New York.

Grunert K. G., Grunert S. C., Sørensen E. (1995), Means-end Chains and Laddering: An Inventory of Problems and an Agenda for Research, MAPP Working Paper no 34.

Grunert K. G., Bech-Larsen T. (2005), Explaining Choice Option Attractiveness by Beliefs Elicited by the Laddering Method, "Journal of Economic Psychology", vol. 26, no 2, https://doi.org/10.1016/j.joep.2004.04.002.

Hamouda M. (2012), Postmodernism and Consumer Psychology: Transformation or Break?, "International Journal of Academic Research in Business and Social Sciences", vol. 2, no 1.

Hirschman E. C., Holbrook M. B. (1982), Hedonic Consumption: Emerging Concepts, Methods and Propositions, "Journal of Marketing", vol. 46, no 3, https://doi. org/10.2307/1251707.

Holbrook M. B. (1996), Special Session Summary Customer Value C: A Framework for Analysis and Research, "Advances in Consumer Research", vol. 23.

Consumer Value: A Framework for Analysis and Research (1999), M. B. Holbrook (ed.), Routledge, London-New York.

Kaciak E. (2011), Market Segmentation Based on Consumer' Cognitive-motivational Structures, "Konsumpcja i Rozwój”, no 1.

Kamakura W. A., Novak T. P. (1992), Value-system Segmentation: Exploring the Meaning of LOV, "Journal of Consumer Research", vol. 19, no 1, https://doi.org/10.1086/209291.

Kuisma T., Laukkanen T., Hiltunen M. (2007), Mapping the Reasons for Resistance to Internet Banking: A Means-end Approach, "International Journal of Information Management", vol. 27, no 2, https://doi.org/10.1016/j.ijinfomgt.2006.08.006.

Lind L. W. (2007), Consumer Involvement and Perceived Differentiation of Different Kinds of Pork - a Means-end Chain Analysis, "Food Quality and Preference", vol. 18, no 4, https://doi.org/10.1016/j.foodqual.2006.10.004. 
Phillips J. M., Reynolds T. J., Reynolds K. (2010), Decision-based Voter Segmentation: An Application for Campaign Message Development, "European Journal of Marketing", vol. 44, no 3/4, https://doi.org/10.1108/03090561011020444.

Proceedings of the 1993 World Marketing Congress (2015), M. J. Sirgy, K. D. Bahn, T. Erem (eds), Developments in Marketing Science: Proceedings of the Academy of Marketing Science, Springer, Cham-London.

Rokeach M. (1973), The Nature of Human Values, Free Press, New York.

Sánchez-Fernández R., Iniesta-Bonillo M. Á. (2007), The Concept of Perceived Value: A Systematic Review of the Research, "Marketing Theory", vol. 7, no 4, https://doi. org/10.1177/1470593107083165.

Solomon M., Bamossy G., Askegaard S., Hogg M. K. (2006), Consumer Behaviour: A European Perspective, 3rd ed., Prentice Hall, Harlow.

Søndergaard H. A. (2005), Market-oriented New Product Development: How Can a Means-end Chain Approach Affect the Process?, "European Journal of Innovation Management", vol. 8, no 1, https://doi.org/10.1108/14601060510578583.

Understanding Consumer Decision Making: The Means-end Approach to Marketing and Advertising Strategy (2001), T. J. Reynolds, J. C. Olson (eds), Routledge, Mahwah, New Jersey.

Wansink B. (2003), Using Laddering to Understand and Leverage a Brand's Equity, "Qualitative Market Research: An International Journal", vol. 6, no 2, https://doi. org/10.1108/13522750310470118.

Zanoli R., Naspetti S. (2002), Consumer Motivations in the Purchase of Organic Food: A Means-end Approach, "British Food Journal", vol. 104, no 8, https://doi.org/ 10.1108/00070700210425930.

\section{Rozwój teorii łańcucha środków i celów - integracja podejścia koncepcji siebie i modelu perspektywy behawioralnej}

(Streszczenie)

Artykuł jest próbą integracji modelu poznawczego łańcucha środków i celów (Means- end Chain - MEC) z jakościowymi podejściami koncepcji siebie i modelami budowanymi w perspektywie behawioralnej (Behavioural Perspective Model - BPM). Zrealizowane zostały w nim trzy cele badawcze. Po pierwsze, scharakteryzowano podejście łańcucha środków i celów, postmodernistyczne nurty badań nad koncepcją siebie i oparty na radykalnych koncepcjach behawioralnych model BPM. Po drugie, zostały omówione podobieństwa i różnice w modelach MEC. Po trzecie, podjęto próbę sformułowania założeń metateorii związanej z rozszerzoną koncepcją łańcucha środków i celów.

Zaprezentowane podejście, uwzględniające podejście koncepcji siebie, podkreśla wielowymiarowe czynniki symboliczne na poziomie mikrostrukturalnym. Z drugiej strony, rozpoznając wzmacniające i hamujące czynniki otoczenia, pozwala na wykorzystanie modeli BPM na poziomie makrostrukturalnym. Wyniki badań otwierają pole nowych możliwości badawczych związanych z rozszerzeniem teorii łańcucha środków i celów i pełniejszej interpretacji zachowań konsumenta.

Słowa kluczowe: zachowanie konsumenckie, teoria łańcucha środków i celów, koncepcja siebie, model perspektywy behawioralnej. 